\title{
11
}

\section{A Mission Too Far? NATO and Afghanistan, 2001-2014}

\author{
Mats Berdal
}

\section{Introduction}

The history and politics of the Western Alliance in the early years of the Cold War provided the backdrop to some of the more specific questions that, under the gentle, inspiring, and highly efficient supervision of Bob O'Neill, informed my doctoral project at Oxford. Benefiting from the release of newly declassified material, I was able to concentrate on the day-to-day politics, dynamics, and actual workings of the Alliance in greater detail than had previously been possible. Bob's training and experience as an historian proved immensely valuable to my efforts.

At some stage in the course of my work, in between time spent in various American and European archives, we decided that I ought perhaps to consult a body of literature subsumed under the rather grand heading of 'alliance theory'. My thesis, after all, was to be submitted in international relations, and some useful propositions and hypotheses might be gleaned from the literature. Much of this literature reflected and was inspired by the aspiration - still very much prevalent in sections of the American political science 
community - to lend scientific rigour to the study of international relations, eschewing what Hedley Bull had famously defined as the 'classical approach' to the subject. ${ }^{1}$

When it came to the viva voce, one of the examiners asked, in probing and typically perceptive fashion, whether the theoretical writings on alliances that I had consulted had really added much to my thesis, let alone to an understanding of the workings of NATO? The implication of the question suggested he thought they had not, and, of course, he was right. I was relieved rather than frustrated. My sense at the time was that Bob, though a historian by training, was always instinctively more comfortable with the classical approach. This approach emphasised the critical importance of a historical perspective in the study of international politics but, in Bull's words, was distinguished by the 'explicit reliance upon the exercise of judgement and by the assumptions that if we confine ourselves to strict standards of verification and proof there is little of significance that can be said about international relations, [and] that general propositions about the subject must therefore derive from a scientifically imperfect process of perception and intuition'. ${ }^{2}$

The approach seemed to me to capture the intellectual temper that infused Bob's reflections on strategy and international politics, as is evident from his writings and contributions to the many debates on the challenges facing the Western Alliance at the time when he was serving as Director of the International Institute for Strategic Studies (IISS) in the 1980s. It is an approach that remains, especially in its emphasis on the importance of historical context and perspective, relevant to an understanding of NATO's post-Cold War history, including the record of its difficult, costly, and drawn out involvement in Afghanistan.

1 Bull, Hedley (1966) 'International Theory: The Case for the Classical Approach', World Politics 18(3).

2 Ibid., p. 361. 


\section{NATO and Afghanistan: Context, Focus, and Argument in Brief}

Created following the International Conference on Afghanistan held in Bonn - and commanded by NATO since August 2003, the International Security Assistance Force (ISAF) formally completed its mission at the end of 2014. Marking the occasion at a meeting of the North Atlantic Council on 17 December 2014, Jens Stoltenberg, NATO's newly appointed Secretary-General, insisted that Afghanistan was now 'more stable and prosperous than ever'. ${ }^{3}$ In his annual report, issued a few weeks later, the Secretary-General again noted how the Alliance had successfully achieved what it had set out to do in Afghanistan. ${ }^{4}$ Given the scale, cost, and longevity of NATO's deployment, an upbeat end of mission report from the chief executive was, perhaps, only to be expected. Even as ISAF was preparing to lower the flag in Kabul, however, the claim that stability (whatever that might mean) had been brought to Afghanistan looked distinctly unconvincing. Since then, developments have only reinforced the fear - widespread among long-standing observers of Afghan history, politics, and society - that few of NATO's achievements, limited as they are, will prove sustainable in the medium to long term. Indeed, one year on from ISAF's withdrawal, there has been a sharp decline in the security situation throughout the country. A faltering, aid-dependent economy wrestling with record levels of unemployment and corruption, a steep increase in the number of people seeking to leave the country, political instability at the centre, and no substantive progress in peace and reconciliation talks with the Taliban, were all combining to ensure that state collapse remained a very real possibility. ${ }^{5}$ Responding to the deteriorating situation, the Obama Administration decided to delay the withdrawal of US forces from the country in October 2015.

\footnotetext{
3 NATO (2014) 'Opening Remarks by NATO Secretary General Jens Stoltenberg at the Meeting of the North Atlantic Council with Past and Current Non-NATO ISAF Contributing Nations', 17 December. Available at: www.nato.int/cps/en/natohq/opinions_116104.htm?selectedLocale=en. 4 NATO (2015) 'The Secretary General's Annual Report 2014', 30 January. Available at: www. nato.int/cps/en/natohq/opinions_116854.htm.

5 Chatham House (2015) 'Developments in and Prospects for Afghanistan', Asia Programme Meeting Summary, 10 November. See also SIGAR (2015) ‘Report of the Special Inspector General for Afghanistan Reconstruction (SIGAR)', 30 July, pp. 93-5. Available at: www.sigar.mil/pdf/ quarterlyreports/2015-07-30qr.pdf.
} 
A full and exhaustive discussion of the reasons behind this bleak picture is beyond the scope the present chapter, whose focus is confined to NATO's mission, activities, and record. The chapter is concerned, in particular, with two issues raised by the history of the Alliance's involvement and the decidedly mixed legacy it leaves behind. While these are closely, indeed inextricably linked, they merit separate treatment for the purposes of analysis.

The first of these concerns the sources of the failure to meet the objective of bringing peace and stability to the country. These are necessarily varied and complex, and the trajectory of developments in Afghanistan over the past decade and a half plainly cannot be ascribed to NATO actions or inactions alone. Chief among NATO's failures and of special interest here - has been a fundamental inability to recognise and engage with the drivers and dynamics of conflict and violence within the country, including the ways in which NATO contributed to mounting insecurity through its actions and those of its member states.

The second issue concerns the politics and functioning of the Alliance. While NATO's long-established planning mechanisms, force generation, and staff procedures 'worked', ${ }^{6}$ and while combat experience was gained and inter-operability improved, the Alliance's overall effort was deeply fragmented. This was a reflection of underlying and never properly reconciled divisions over objectives among allies. Put differently, NATO never functioned as an effective coalition of allies bound together by a common strategic vision and clarity of objectives in Afghanistan; it always remained less than the sum of its parts. At one level, this reality reflected differing views about the appropriate level of ambition for NATO in Afghanistan, with the US consistently sceptical of what was dismissively termed (and not just by the Bush Administration) the nation-building ambitions of many European allies. Many of those allies, in turn, deplored the dominant and overriding influence in US decision-making of a much more narrow counter-terrorism perspective, especially within the Pentagon, CIA, and the US military. Equally important in terms of explaining

6 For a perceptive and illuminating discussion of how 'the system worked', looking at the escalation of international involvement after 2001, and drawing upon Leslie Gelb's famous 1971 article tracing America's deepening involvement in Vietnam, see Suhrke, Astri (2011) When More is Less: The International Project in Afghanistan, London: Hurst \& Co., pp. 4-5. For Gelb's original article, see Gelb, Leslie H. (1971) 'Vietnam: The System Worked', Foreign Policy 3. 
NATO's fragmented approach, however, were the domestic political pressures and considerations, often extraneous to Afghanistan itself and developments there, which shaped the commitments of individual allies to NATO's mission.

\section{The Evolution of NATO's Afghanistan Mission}

In order to explore these issues more fully, it is necessary to start by tracing the evolution of NATO's mission to Afghanistan. This is a history of initial engagement, escalating involvement and rapid withdrawal, which can usefully be divided into three periods.

\section{1-2003: Engaging Allies in 'appropriately flexible ways'}

NATO only assumed responsibility for ISAF in Kabul in 2003, and did not complete the gradual expansion of its mission to cover the whole of Afghanistan until October 2006. However, any attempt to understand the history of the Afghanistan mission must start with the strategic decisions that were taken, and those that were not, by the US in response to the terrorist attacks of 11 September 2001.

The shock, scale, and horror of those attacks led to a near universal outpouring of sympathy and support for the US. This was exemplified by the Security Council's prompt condemnation of the attacks as 'threats to international peace and security' and its reaffirmation of the US's right of individual and collective self-defence. ${ }^{7}$ On the very same day that the Security Council passed its resolution, the North Atlantic Council invoked Article V of the Washington Treaty for the first time in its history. The so-called 'collective defence provision' stipulated that an 'an armed attack against one or more of them in Europe or North America shall be considered an attack against them all' ${ }^{8}$ Much was made at the time, and since, about this unprecedented move on the part of the Alliance. As a demonstration of support and solidarity with the US, the symbolism could not have been greater. And yet, the military and operational significance of the Article $\mathrm{V}$

7 UN Security Council Resolution 1368, 12 September 2001.

8 The North Atlantic Treaty, 4 April 1949, Article V. 
invocation soon proved negligible. As preparations for military and covert actions in Afghanistan got under way in the weeks following the 9/11 attacks, the Bush Administration had no desire to involve NATO directly in operations through its collective assets, or command and planning structures. Paul Wolfowitz, Deputy Defence Secretary at the time, summed up the administration's view of NATO and its role on the eve of the attack on Afghanistan:

We think we had a collective affirmation of support with what they said with Article Five, and if we need collective action we'll ask for it. We don't anticipate that at the moment ... We need cooperation from many countries but we need to take it in appropriately flexible ways. ${ }^{9}$

Wolfowitz's comments and the subsequent unfolding of the campaign in 2001 point to two aspects of US policy that help explain the dynamics of Alliance relations for the entire period of NATO's involvement.

First, in taking the 'battle to the terrorists, to their networks and to those states and organizations that harbor and assist terrorist networks ${ }^{\prime},{ }^{10}$ the US did not wish to be constrained. The Authorization for Use of Military Force (AUMF), passed by congress on 14 September 2001, was open-ended, both in terms of time and geographical scope. ${ }^{11}$ Operation Enduring Freedom (OEF), formally launched with the attack on Afghanistan on 7 October 2001, was a counter-terrorism mission broadly conceived. Indeed, to US decision-makers it was 'the opening salvo in a global war on terror' ${ }^{12}$ Following the toppling of the Taliban regime and the inauguration of an interim Afghan Government in late December 2001, thought gradually turned to how stability might be extended throughout the country. Even so, OEF's central focus on 'disrupting, dismantling and defeating Al-Qaeda and Taliban' fuelled by the desire for retribution and revenge, especially in the early days - remained a dominant strategic priority throughout

9 Paul Wolfowitz, Press Conference, NATO HQ, 26 September 2001, quoted in Kreps, Sarah E. (2011) Coalitions of Convenience: United States Military Interventions after the Cold War, Oxford: Oxford University Press, pp. 95-6.

10 Washington Post (2001) 'Text: Rumsfeld's Pentagon News Conference', 18 October. Available at: www.washingtonpost.com/wp-srv/nation/specials/attacked/transcripts/rumsfeld_ text101801.html.

11 The AUMF remains in force.

12 Stapleton, Barbara J. and Michael Keating (2015) Military and Civilian Assistance to Afghanistan 2001-14: An Incoherent Approach, London: Chatham House, p. 2. Available at: www. chathamhouse.org/sites/files/chathamhouse/field/field_document/20150722MilitaryCivilian AssistanceAfghanistanStapletonKeating.pdf. 
the period of NATO's engagement. The Bush Administration's aversion to nation-building was well known before 9/11, and explains why it successfully resisted calls for ISAF to be expanded outside Kabul before 2003. Scepticism about ambitious postwar objectives was also widely shared, notably by Robert Gates who, upon taking office as Secretary of Defence in 2006, was quick to conclude that 'our efforts [in Afghanistan] were being significantly hampered by muddled and over-ambitious objectives' ${ }^{13}$ Defining the strategic objectives for Afghanistan set the US apart from many European NATO allies. Gates himself, looking back, felt the divergence of views between European approaches 'that looked a lot like nation-building' and much narrower US objectives remained 'an important and underlying source of friction and frustration' within NATO. ${ }^{14}$

Second, Wolfowitz' remarks made it clear that while the US welcomed the support of individual allies in its global and open-ended war on terror, NATO as an alliance - with its limited collective assets, wellestablished planning procedures, and consultative mechanisms - was more likely to complicate, even restrict, US freedom to respond as it saw fit. The prevailing view held by American officials of NATO's Kosovo operation in 1999, especially in the Pentagon and within the military, reinforced this sentiment. Now, in the post-9/11 world, the mission would always 'determine the coalition', as Rumsfeld made clear from the outset. ${ }^{15}$

Over time, as security deteriorated and challenges mounted in Afghanistan and Iraq, following its invasion by the US and the UK in 2003, the importance and uses of allies became more apparent: they could help legitimise the need for continuing involvement internally to congress (which controlled the purse strings) and to an increasingly war-weary public; they could assume the burden of nation-building tasks; and some allies might even provide useful assets (for example, contributing intelligence and special operations forces). At the end of the day, however, NATO per se was of limited use and interest, a sense

\footnotetext{
13 Gates, Robert (2014) Duty, London: W. H. Allen, p. 203.

14 Ibid.

15 Washington Post (2001) 'Text: Rumsfeld's Pentagon News Conference', 18 October. Available at: www.washingtonpost.com/wp-srv/nation/specials/attacked/transcripts/rumsfeld_ text101801.html.
} 
captured by Gates' admission that he struggled to stay awake during NATO meetings, finding them 'excruciatingly boring', as 28 countries rattled through their pre-prepared scripts. ${ }^{16}$

There is a final aspect to the early phase of operations in Afghanistan and the strategic choices then made by the US, which crucially shaped the context of NATO's expanding involvement from 2003 onwards. What was soon dubbed the 'Afghan Model'17 of operations - a very light conventional footprint, relying instead on special operations forces, precision weapons, and local allies, in the form of the Northern Alliance, to overthrow the Taliban regime - combined with a rejection of nation-building and an unwillingness to invest in the search for a broader, more inclusive political settlement following the collapse of the Taliban in 2001 had very important long-term consequences. The Bush Administration's postwar plan, as one perceptive study would later put it, 'seems to have been to pass control of the country as quickly as possible to local proxies who had assisted international forces and thereafter to retain a residual counterterrorism mission' ${ }^{18}$ In the process of doing so, US forces entered into alliances with local and regional strongmen and warlords, men such as Ismail Kahn and Gul Aga Shirzai, many of whom had risen to prominence during the horrific civil war that had engulfed the country after $1992 .{ }^{19}$ This development and the dynamic set in motion by cultivating relations with venal, predatory, and violent warlords set the stage for renewed conflict. As Alex Strick van Linschoten and Felix Kuehn concluded when examining developments after the fall of the Taliban regime, the 'strategic mistake of handing over the government to former strongmen and warlords ... aided the Taliban's return'. ${ }^{20}$ Crucially, bringing warlords and their tribally based

16 Gates, Robert (2014) Duty, London: W. H. Allen, p. 194.

17 Biddle, Stephen (2003) 'Afghanistan and the Future of Warfare', Foreign Affairs 82(2), pp. 31-45. Available at: www.foreignaffairs.com/articles/afghanistan/2003-03-01/afghanistanand-future-warfare.

18 Wilton Park (2015) 'Capturing the Lessons from the Helmand Provincial Reconstruction Team (PRT)', Wilton Park Report WPR1322, p. 11.

19 On Gul Agha Sherzai and the local impact of his alliance with US forces in their war on terror, see Gopal, Anand (2014) No Good Men Among the Living: America, the Taliban and the War through Afghan Eyes, New York: Metropolitan Books, pp. 107-10.

20 van Linschoten, Alex Strick and Felix Kuehn (2012) An Enemy We Created: The Myth of the Taliban/Al Qaeda Merger in Afghanistan, 1970-2011, London: Hurts \& Co., p. 254. See also van Bijlert, Martine (2009) 'Unruly Commanders and Violent Power Struggles: Taliban Networks in Uruzgan', in Antonio Giustozzi (ed.), Decoding the New Taliban, London: Hurst \& Co., pp. 158-60. 
patronage networks into positions of power at the local and district level gave rise to a distinctive political economy of conflict that would continue to confound NATO's attempts, starting in 2003, to stabilise the country through aid, reconstruction, and development assistance (as discussed more fully below).

\section{3-2009: Expanding Mission, Growing Insurgency}

NATO assumed command of ISAF in August 2003. Soon thereafter it was authorised by the UN Security Council under Chapter VII to expand ISAF's presence outside 'Kabul and its environs' with the aim of establishing security and extending the writ of the government to 'all parts of Afghanistan'. ${ }^{21}$ By October 2006, following a phased anticlockwise expansion - starting in the north in 2004 and ending with a surge in the south and east in 2006 - ISAF's area of responsibility covered the whole of the country. Accompanying the process was the creation of a complex and top-heavy structure of regional command headquarters, contributing to making NATO forces, in the words of one senior official, 'high on tail, low on teeth'.$^{22}$ Formally under ISAF's command by late 2006 were also some 25 Provincial Reconstruction Teams (PRTs) operating from local bases. These were multinational teams, combining civilian and military elements, led by individual nations, whose role was to 'deliver a "stabilisation effect"' by facilitating 'reconstruction, security, governance, aid and development'. ${ }^{23}$ As such, the PRTs were critical to NATO's stated ambition of 'extending the influence of the central government' ${ }^{24}$

The expansion of NATO's role after 2003 requires explanation. ${ }^{25}$ After all - and it is an argument that has often been made since the Taliban had been toppled, its foot soldiers had scattered and alQaeda was, if not defeated, weakened and without a safe haven in the country.

\footnotetext{
21 UNSC 1510, 13 October 2003.

22 Interview with NATO Official, June 2015.

23 Wilton Park (2015) 'Capturing the lessons from the Helmand Provincial Reconstruction Team (PRT)', Wilton Park Report WPR1322, p. 5.

24 Speech at IISS by NATO Secretary General, Jaap de Hoop Scheffer, 12 February 2004.

25 Numbering some 5,000 and confined to Kabul in September 2003, NATO ISAF troop levels grew to 33,000 in 2006, and would eventually peak - following the 2009-11 surge - at more than 130,000 in July 2011.
} 
A combination of three factors drove NATO's growing involvement. The first was a strong, if confused and strategically inchoate, sense among allies that the Alliance needed to carve out a more clearly defined role for itself in the post-9/11 security landscape. To this end, the Prague meeting of NATO Heads of State and Government, held in November 2002 and dubbed the 'transformation summit', famously signalled NATO's readiness to go out-of-area in order to take on new and global challenges.

The second factor was related. With US attention and resources increasingly focused on Iraq and, soon after its invasion in 2003, fully absorbed by the catastrophic consequences of state collapse in that country, pressure mounted for NATO allies to pick up the burden in Afghanistan. The readiness to do so was aided by the deep divisions that existed over US actions in Iraq (in contrast to the emerging narrative of 'a good war' in Afghanistan), but also the growing realisation among European allies that Afghanistan was not 'mission accomplished' in late 2001. This was the third factor that drove NATO's deepening involvement: a sense among European allies, that, above all, 'the interveners now had an obligation to deliver more than a government of warlords ${ }^{\prime 26}$ To meet that obligation, NATO developed and regularly updated its Comprehensive Strategic Political Military Plan for Afghanistan once it had assumed command of ISAF. Its vision and underlying idea, as summarised by Keating and Stapleton, remained basically unchanged:

$[\mathrm{O}] \mathrm{n}$ the basis of reconstruction and development, the Afghan government would extend its legitimacy and authority countrywide, thereby enabling its international partners to help build a sustainable stability that would foster economic development. This 'end state' would allow a military exit with continued foreign assistance typical of other post-conflict fragile states. ${ }^{27}$

26 Wilton Park (2015) 'Capturing the lessons from the Helmand Provincial Reconstruction Team (PRT)', Wilton Park Report WPR1322, p. 11.

27 Stapleton, Barbara J. and Michael Keating (2015) Military and Civilian Assistance to Afghanistan 2001-14: An Incoherent Approach, London: Chatham House, p. 4. 
The script did not pan out as envisaged. Instead, the period between 2006 and 2009 saw NATO confronted with a 'growing and resilient insurgency' ${ }^{28}$ Even as troop and aid levels rose, and a comprehensive approach that emphasised integrated working between the military and civilian arms of NATO's effort was formally adopted, the much vaunted stability effect proved ever more elusive. As combat operations intensified, especially in the south of the country, security continued to deteriorate. Indeed, it is a striking fact, as Graeme Smith observed, and which ought to have given pause for thought, that 'every increase in troop numbers in southern Afghanistan brought a corresponding increase in violence' ${ }^{29}$

\section{9-2014: COIN and Transition to 'Afghan lead for security'}

By early 2009, with a new administration in power in Washington, an increasingly war-weary public, and a president intellectually and emotionally committed to bringing America's 9/11 wars to an end, the situation in Afghanistan was deemed to 'demand urgent attention and swift action'. ${ }^{30}$ An immediate increase in US troop numbers (of some 17,000) was ordered in March 2009, along with a reaffirmation of the central aim of US policy: 'to disrupt, dismantle and defeat al Qaeda in Pakistan and Afghanistan, and to prevent their return to either country in the future. ${ }^{31}$ To this end, the counter-terrorism operations emphasising kill and capture were also intensified, as the skills and methods developed in Iraq were transferred to Afghanistan. In July 2009, Stanley McChrystal, shortly after assuming command of NATO ISAF, was asked to conduct a multidisciplinary assessment of the

\footnotetext{
28 McChrystal, Stanley (2009) 'Commander's Initial Assessment', Commander NATO ISAF, Afghanistan/US Forces, 30 August. Available at www.washingtonpost.com/wp-dyn/content/ article/2009/09/21/AR2009092100110.html.

29 Smith, Graeme (2013) The Dogs are Eating them Now: Our War in Afghanistan, Berkeley: Counterpoint, p. 169. Remarkably, even the intensive 'kill-and-capture' campaign of 2010-11, which saw thousands of night raids and operations aimed at breaking the back of the insurgency, did not lead to 'a significant downturn in violence or insurgent attacks'. van Linschoten, Alex Strick and Felix Kuehn (2012) An Enemy We Created: The Myth of the Taliban/Al Qaeda Merger in Afghanistan, 1970-2011, London: Hurts \& Co., p. 315.

30 'Statement by the President on Afghanistan', 17 February 2009, White House Press Release. 31 'Remarks by the President on a New Strategy for Afghanistan and Pakistan', 27 March 2009, White House Press Release.
} 
situation in Afghanistan and present military options. ${ }^{32}$ Faced with the prospect of 'strategic defeat', McChrystal concluded that a 'significant change to our strategy and the way we think and operate' was needed. ${ }^{33}$ He called for a 'comprehensive counter-insurgency (COIN) campaign' focused on protecting the population, strengthening the Afghan National Security Forces (ANSF) and 'improving governance at all levels'. ${ }^{34}$ Following a protracted and deeply divisive internal debate about the way forward, Obama endorsed the new approach. Reflecting his long-term desire to end US combat commitments, and conscious of growing war-weariness among the public, he opted for a more limited troop surge of 30,000. At the same time, he made it clear that the drawdown of US troops and transfer of responsibility for security to ANSF would start no later than July 2011.

Where the US led, NATO allies followed. In support of Obama's surge, NATO ministers pledged to deploy another 7,000 troops. ${ }^{35}$ The shift in focus towards transition and eventual withdrawal was formally endorsed by NATO members at the Lisbon Summit in November 2010. It was agreed that Afghan forces would assume 'full responsibility for security across the whole of Afghanistan' by the end of 2014. ${ }^{36}$ At the time, NATO ministers insisted that the pace of transfer of responsibility to Afghan security forces would be 'conditions-based, not calendar-driven', and that transition would not simply 'equate to withdrawal of ISAF-troops' ${ }^{37}$ Domestic political pressures and war weariness in NATO countries, however, ensured that the transitional process never stood much chance of being truly conditions-based. ${ }^{38}$

32 McChrystal, Stanley (2009) 'Commander's Initial Assessment', Commander NATO ISAF, Afghanistan/US Forces, 30 August. Available at www.washingtonpost.com/wp-dyn/content/ article/2009/09/21/AR2009092100110.html.

33 Ibid.

34 Ibid.

35 In 2009, the NATO Training-Mission Afghanistan also activated. It was set up to train and help professionalise Afghan security forces in preparation for the transfer of responsibility for security.

36 NATO (2010) 'Lisbon Summit Declaration', 20 November. Available at: www.nato.int/cps/ en/natolive/official_texts_68828.htm.

37 Ibid.

38 For the condition of the Afghan army one year on from ISAF's departure, see Amiri, Sharif (2016) 'NATO Report Slams Afghan Army as Mission Incapable', Tolo News, 10 January. Available at: www.tolonews.com/en/afghanistan/23228-nato-report-slams-afghan-army-asmission-incapable. 
Indeed, the quip that President Obama's strategy for the Afghan endgame was best summed up by 'surge, bribe and run' ${ }^{39}$ proved uncomfortably close to the mark.

\section{Explaining NATO's Record in Afghanistan: The Sources of Failure}

How do we explain the failure on the part of NATO and its partner nations to bring stability to Afghanistan between 2001 and 2014? While a full and detailed answer to this question is beyond the scope of the present chapter, the history and pattern of involvement sketched above point to three sets of issues which, though closely related, merit separate attention:

- the debilitating impact of conflicting and competing objectives on Alliance cohesion and unity of purpose, notably between the US and its European allies;

- the inability of individual allies operating within their geographic areas of responsibility, and of NATO as a whole, to appreciate and grapple with underlying sources of violence and conflict in Afghanistan; and

- the inherent difficulties of applying NATO's approach to stabilisation and COIN in the case of Afghanistan.

\section{Conflicting and Competing Objectives}

The central fault-line, in terms of the overall political objective for the campaign, remained the tension between the US focus on counterterrorism, broadly defined, and a more ambitious set of state- and peace-building objectives held by coalition partners. This gave rise to conflicting priorities on the ground and a fragmentation of effort from the outset. The tension was not always easily gleaned from upbeat and soothing NATO communiqués that emphasised the Alliance's 'comprehensive approach to crisis management' and its delivery

39 Brahma Chellaney quoted in Thakur, Ramesh (2015) 'With the Benefit of Hindsight: Chronicling Afghanistan Errors', in Jack Cunningham and W. Maley (eds), Australia and Canada in Afghanistan: Perspectives on a Mission, Toronto: Dundrun Press, p. 220. 
of 'stabilisation and reconstruction effects'. ${ }^{40}$ But it was always there. Given the dominant influence of the US in terms of decisionmaking power and resources (especially following the surge in 2009-2010), ${ }^{41}$ the counter-terrorism perspective would always trump other considerations, within the Alliance as well as within internal administration debates on Afghan policy. The counter-terrorism perspective remained premised on a broad and permissive definition of terrorists and insurgents - one that never seriously questioned 'the supposedly unbreakable link between the Taliban and al-Qaeda' ${ }^{42}$ As a result, the scope for exploring a wider political settlement to end the war, as called for by Richard Holbrooke in the face of internal opposition in 2010, and strongly favoured by European allies, was always limited and never won through at critical moments.

In terms of operations and activities, the tension between strategic priorities gave rise to, and were reflected in, a complicated and dysfunctional set of command and control arrangements that included multiple and separate chains of command, both within theatre and between capitals and theatre. Most obvious in this respect was the separation of OEF from NATO's ISAF mission, though it was evident at other levels too, notably in the deployment and activities of US Special Operations Forces (elements of which reported directly to Tampa, Florida) and, significantly, in workings of the nationally led PRTs. ${ }^{43}$ The variety of models and approaches adopted by different PRTs were, to a degree, a function of location, resources, and national styles. As a result, they operated with a high degree of autonomy and only loose direction from ISAF regional headquarters. Adaptation to circumstances is to be valued in many contexts but, as Jackson and Gordon perceptively noted in 2007, for NATO states to extoll virtues of

40 NATO (2010) 'Lisbon Summit Declaration', 20 November. Available at: www.nato.int/cps/ en/natolive/official_texts_68828.htm.

41 In the words of one of NATO's Senior Civilian Representatives (SCR), as US military and civilian assistance efforts increasingly came to dwarf that of others, allies and coalition partners were left 'outside the magic circle comprised of the US ambassador and the US military commander in Kabul where the actual decision-making took place'. NATO SCR quoted in Stapleton, Barbara J. and Michael Keating (2015) Military and Civilian Assistance to Afghanistan 2001-14: An Incoherent Approach, London: Chatham House, p. 5.

42 van Linschoten, Alex Strick and Felix Kuehn (2012) An Enemy We Created: The Myth of the Taliban/Al Qaeda Merger in Afghanistan, 1970-2011, London: Hurts \& Co., p. 326.

43 On the subject of command and control, drawing attention also to the striking lack of unity within US forces in Afghanistan, see Cowper-Coles, Sherard (2011) Cables from Kabul: The Inside Story of the West's Afghanistan Campaign, London: Harper Press, pp. 163-5. 
diversity was also 'a ruse for justifying both national agendas and the absence of an effective strategic framework in which the PRTs could operate' ${ }^{44}$ The bilateral provision of aid, reconstruction, and security assistance by PRTs within their respective areas of responsibility created national bubbles, further undermining attempts at achieving strategic coherence overall.

Ed Butler, who led the British Task Force that deployed to the south in 2005 and 2006, would later reflect on the overall consequences:

[T] he main challenge to the creation of a coherent political-military strategy was the existence of multiple missions set by all the different stakeholders and nations, all with their own definitions of success and failure. In other words, there was a 'split planning effort' from the start. At the operational level, we used the term 'duality of mission' to describe this tension: NATO's objective of nation-building and reconstruction vis-à-vis the US objective of counter-terrorism. The ends, ways and means of the two missions were diametrically opposed. ${ }^{45}$

\section{Drivers of Violence and Insecurity: Local Context, Political Economy, and Nationalism}

The contribution of NATO and partner nations to security and stabilisation efforts in Afghanistan — collectively and individually within their respective sectors of operations - was critically undermined from the outset of ISAF's expansion outside Kabul by a persistent failure to properly grasp some key, underlying drivers of conflict. This was even more notably so from 2006, when combat operations intensified. Two aspects of this deserve special attention.

The first was the way in which local context and the distinctive political economies of conflict within Afghanistan drove violence and insecurity throughout the provinces. The latter was shaped by complex ethno-tribal grievances, local politics, and power struggles, often with deep historical roots, and all set within the patronagebased and nepotistic post-Taliban political order that emerged in 2001 and 2002. This reality contrasted sharply with the dominant narrative

44 Jackson, Matthew and Stuart Gordon (2007) 'Rewiring Interventions?: UK Provincial Reconstruction Teams and "Stabilization"', International Peacekeeping 14(5), p. 649.

45 Butler, Ed (2015) 'Setting Ourselves up for a Fall in Afghanistan', RUSI Journal 160(1), p. 49. 
through which NATO, led by the US (and within the US, led by the Pentagon and the military), understood and approached the Afghan conflict. Aptly termed the 'insurgency narrative' ${ }^{\prime 6}$ by Mike Martin, this effectively reduced the struggle in Afghanistan to, on the one hand, a legitimate government seeking to build the foundations of a modern, democratic, and liberal-looking state, supported in that endeavour by the West, and, on the other, a retrograde, ideologicallydriven Taliban insurgency, benefiting from sanctuaries in and support from Pakistan. While this view was not without some foundation in fact, it profoundly and fatally simplified what was actually driving dynamics in places where NATO operated. As one study of the British experience between 2006 and 2014 in Helmand - though of much wider relevance to an understanding of NATO's overall campaign perceptively emphasised:

The localised nature of the insurgency and the local grievances and rivalries that shaped how different local actors aligned and realigned themselves in relation to the 'government' and 'Taliban' figures frequently had far less to do with the macro-dynamics of insurgency and counter-insurgency than they did with complex local political dynamics including the narco-economy and power relations between rival social groups. ${ }^{47}$

This failure to understand the interaction of the conflict's microdynamics with patronage politics and struggles over power and resources at the centre, meant that the actions of NATO allies often played into and contributed to the entrenchment of violent and exploitative political economies in perverse and unintended ways. The most striking, and now well documented, examples of this are effects of UK-led counter-narcotics policies. The initial attempts at eradication, pursued in Helmand where opium production and the narcotics industry was the main source of livelihood to thousands of farmers, and of power and profits to officials and strongmen inside

46 Martin, Mike (2014) An Intimate War: An Oral History of the Helmand Conflict, London: Hurst \& Co, p. 195.

47 Wilton Park (2015) 'Capturing the lessons from the Helmand Provincial Reconstruction Team (PRT)', Wilton Park Report WPR1322, p. 4. In fact, as the study concluded, 'the "Taliban" fought for a variety of reasons and while there were certainly "ideological" fighters in Helmand who were committed to the Quetta Shura, the majority of insurgents may have fought less out of commitment to the Taliban ideology than (as they saw it) on the basis of local issues, including a desire to protect their crops or localised grievances relating to access to land and water or more provincial level horizontal inequalities'. Ibid., p. 21. 
and outside the province, provide a pertinent example. As discussed more fully below, this much more complex picture of the sources and dynamics of insecurity fundamentally challenged the premises on which NATO's stabilisation, as well as NATO and American COIN efforts, were predicated.

The second aspect, more difficult to pin down and measure, but no less important, was the role played by NATO and the Westernled intervention generally in stimulating Afghan nationalism and anti-foreign sentiment, especially in the Pashtun belt in the south. ${ }^{48}$ Familiarity with Afghan history should, but never seems to have, alerted outsiders to the likely importance of the innate resistance to foreign intrusion and control in the country. It was perhaps a failure linked, as Anatol Lieven has suggested, to the tendency to treat Afghanistan as a 'landscape of the mind, onto which Westerners could project a variety of agendas and fantasies' ${ }^{49}$ This said, suspicion and resentment towards the international coalition, and certainly the intensity it acquired over time, were not given. Taliban's removal in 2001 was generally welcomed, and hope appears to have been widespread that an extended period of civil war would finally come to an end and a more just political dispensation emerge. Several factors soon served to undermine that hope.

One of these was the return to power and influence of the warlords and strongmen that had been so prominent during the deeply destructive civil war of 1992-1996. The basic attitude taken towards these warlords and strongmen by the US was pithily summed up by Ahmed Rashid: 'a cheap and beneficial way to retain US allies in the field who might even provide information about al Qaeda. ${ }^{50}$ By 2004, their abusive, predatory, and corrupt behaviour was fuelling the Taliban revival, and feeding into suspicion and conspiracy theories about the real motives of NATO's presence.

48 On this, see findings of Graeme Smith's so-called 'Taliban survey' based on interviews conducted with Taliban fighters in 2007 and 2008 and discussed in Smith, Graeme (2013) The Dogs are Eating them Now: Our War in Afghanistan, Berkeley: Counterpoint, chapter 8. 49 Lieven, Anatol (2010) 'Insights from the Afghan Field', OpenDemocracy. Available at: www. opendemocracy.net/anatol-lieven/insights-from-afghan-field.

50 Rashid, Ahmed (2008) Descent into Chaos, London: Allan Lane, p. 129. See also Gopal, Anand (2010) 'Flash to the Past: Missed Opportunities for Reconciliation', Afghanistan Analysts Network. Available at: www.afghanistan-analysts.org/flash-to-the-past-missed-opportunitiesfor-reconciliation/. 
Local nationalisms and anti-foreign resistance were also powerfully stimulated by the conduct and fall-out of military operations, especially from 2006, when the number of civilian casualties from NATO operations began to rise steeply. An authoritative study drawing upon surveys in five of Afghanistan's provinces (Helmand, Paktia, Uruzgan, Balkh, and Faryab) conducted between 2008 and 2010, found that the behaviour of troops, especially in areas where levels of insecurity were high, was widely viewed as disrespectful of 'Afghan culture, religion, and traditions', and became an significant 'driver of insecurity'. ${ }^{51}$ As an inevitable result, trust in NATO-ISAF declined. In the words of one former provincial governor, interviewed in January 2009: 'people are slowly but surely coming to the conclusion that they are an occupied country. As a result of the bombings, house searches, being bitten by dogs, people are thinking that the US is worse than the Soviets. ${ }^{52}$ While the problem was recognised by many, attempts to address it remained half-hearted, and the conduct of operations continued to cause resentment and 'push people to join the insurgency' ${ }^{53}$ Recognising the counterproductive effects of air strikes and night raids on efforts to win hearts and minds, General McChrystal temporarily tightened restrictions on the use of force by US troops soon after assuming command of ISAF. These, however, were soon lifted again by General Petraeus who, upon replacing McChrystal in mid-2010, ordered a sharp increase in number of night raids by special operations forces in an attempt to decapitate the insurgent leadership before the drawdown of troops began in earnest.

It is worth adding here that whatever the diversity of views within the Alliance about mission objectives, and whatever degree of experimentation took place in individual PRTs, most Afghans, key regional actors (and, indeed, much of the wider international community) never distinguished clearly between NATO, and the US and its broad counter-terrorism focus. This perception was plainly not

51 Fishstein, Paul and Andrew Wilder (2012) Winning Hearts and Minds?: Examining the Relationship between Aid and Security in Afghanistan, Medford: Feinstein International Centre, Tufts University, p. 35. Available at: fic.tufts.edu/assets/WinningHearts-Final.pdf.

52 Quoted in ibid.

53 This was among the more notable findings of Graeme Smith's aforementioned 'Taliban survey', see Smith, Graeme (2013) The Dogs are Eating them Now: Our War in Afghanistan, Berkeley: Counterpoint, p. 205. See also Lieven, Anatol (2010) 'Insights from the Afghan Field', OpenDemocracy. Available at: www.opendemocracy.net/anatol-lieven/insights-from-afghan-field. 
without basis in fact, however much it also concealed a more complex picture - there were, for example, differences in behaviour among contingents, with some notably more aggressive than others. ${ }^{54}$

\section{The Assumptions of Stabilisation and COIN}

The fundamental, though on closer inspection far from unproblematic, assumption that governed NATO's mission in Afghanistan was that aid, development, and reconstruction would progressively help stabilise insecure areas. Doing so, like a virtuous cycle, would simultaneously serve to strengthen the legitimacy and authority of central government. ${ }^{55}$ The PRTs, focusing resources on development projects that would produce quick wins - roads, hospitals, wells, and local infrastructure projects of different kinds - were the instruments through which the stabilisation effect would be delivered. The belief that aid and Quick Impact Projects (QIPs) could help win hearts and minds also underpinned the COIN strategy explicitly adopted in 2009, and saw astonishing amounts of money injected into local economies in support of reconstruction projects (in the US case through the so-called Commanders Emergency Response Program).

The assumption was problematic for at least two closely connected reasons. In the first instance, it rested on (or seemed to take for granted) the view that the government of Hamid Karzai enjoyed political legitimacy. In fact, the Karzai Government was widely and increasingly seen by many as weak, corrupt, and abusive. Following the toppling of the Taliban in 2001, Northern Alliance commanders quickly set about consolidating local power bases, using tribal networks, and access to central government to seize the state apparatus in local districts and provinces. This in turn enabled them to capture and influence the distribution of aid and development funding. The upshot was to alienate those outside the patronage networks of corrupt and violent strongmen, and to further weaken the legitimacy of an already weak central government. This helps explain why the aforementioned

54 On aggressive behaviour of troops, see Smith, Graeme (2013) The Dogs are Eating them Now: Our War in Afghanistan, Berkeley: Counterpoint, p. 162, and see Chandrasekaran, Rajiv (2012) Little America: The War Within the War for Afghanistan, London: Bloomsbury, p. 277.

55 Indeed, this assumption is central to 'clear-hold-build', which in 2009 was NATO's 'preferred operational approach' to counter-insurgency. See Ucko, David H. (2013) 'Beyond Clear-Hold-Build: Rethinking Counterinsurgency at the Local Level', Contemporary Security Policy 34(3), p. 526. 
study of aid and reconstruction in five of Afghanistan's provinces found so 'little concrete evidence ... that aid projects were having more strategic level stabilisation or security benefits such as winning populations away from insurgents, legitimising the government, or reducing levels of violent conflict'. ${ }^{56}$ Quite the opposite was the case, with 'more evidence of the destabilizing rather than the stabilizing effects of aid, especially in insecure areas where the pressures to spend large amounts of money quickly were greatest' ${ }^{\prime}{ }^{57}$

The second factor flowed directly from this. NATO proceeded in Afghanistan on the assumption that insecurity and sources of instability emanated from a resurgent Taliban, rather than a much more complex and multilayered set of sources. Such sources included rapacious government officials, and long-standing ethnic, tribal, and local grievances, fuelled by an exploitative political economy. This reality doomed a population-centred counterinsurgency campaign aimed at drawing the population away from insurgents and towards the government. As Karl Eikenberry, American Ambassador to Kabul from 2009 and 2011, and with two tours of military duty to Afghanistan before that, noted:

'Protect the population' makes for a good bumper sticker, but it raises the question: Protect it from whom and against what? It certainly meant protecting the Afghan people from marauding Taliban insurgents. But what about criminal narco-traffickers, venal local police chiefs, or predatory government officials? ${ }^{58}$

Not surprisingly, expressing such views earned him few friends at the Pentagon and among senior officers committed to COIN during the internal strategy debates. He had nonetheless honed in on a critical problem underlying the COIN philosophy as applied to Afghanistan.

Underlying all of this, and much of the discussion above, was the deeper failure to appreciate the political nature and drivers of conflict, that is, the extent to which violence was driving the competition over power

56 Fishstein, Paul and Andrew Wilder (2012) Winning Hearts and Minds?: Examining the Relationship between Aid and Security in Afghanistan, Medford: Feinstein International Centre, Tufts University, p. 3.

57 Ibid.

58 Eikenberry, Karl W. (2013) 'The Limits of Counterinsurgency Doctrine in Afghanistan', Foreign Affairs 92(5). Available at: www.foreignaffairs.com/articles/afghanistan/2013-08-12/ limits-counterinsurgency-doctrine-afghanistan. 
and resources among elites. ${ }^{59}$ Recognition of this dynamic should have encouraged the pursuit, with the same fervour and aggression as the military campaign, of a political strategy aimed at reconciliation and a more inclusive political settlement.

\section{The Politics and Functioning of the Alliance}

The discussion above has focused on why an unprecedented amount of resources and effort on the part of NATO and partner countries, invested at great human cost over a period of 13 years, produced results so much at variance with the declared objectives of bringing lasting peace and stability to Afghanistan. ${ }^{60}$ Addressing that question is obviously of the highest priority. The question is not, however, precisely the same as asking how NATO functioned as an alliance and why the mission unfolded in the way it did. To answer that question, two additional drivers of institutional response need to be factored into the analysis.

In the first instance, and as noted earlier, NATO's growing involvement in Afghanistan from 2003 was linked to the widespread post-9/11 perception, shared by NATO capitals, that the Western Alliance needed to demonstrate its continuing relevance in the face of new and global challenges in the interests of institutional survival, 'in particular, those posed by terrorism and the proliferation of weapons of mass destruction' ${ }^{61}$ No longer held together by the unifying perception of a common Cold War threat, and with a more recent patchy record of operations in the Balkans to show for its efforts, NATO needed to prove its credibility. Assuming a greater role in Afghanistan came to be seen as the test of NATO's transformation in the face of changing security threats and risks that transcended the Euro-Atlantic area. High-flown summit declarations notwithstanding, deep differences

59 A point also strongly emphasised in Fishstein, Paul and Andrew Wilder (2012) Winning Hearts and Minds?: Examining the Relationship between Aid and Security in Afghanistan, Medford: Feinstein International Centre, Tufts University, pp. 57-9.

60 As an illustration of the sums involved, by mid-2015 the cumulative appropriations for US 'relief and reconstruction' alone had reached some \$110 billion. SIGAR (2015) 'Report of the Special Inspector General for Afghanistan Reconstruction (SIGAR)', 30 July, p. 78. Available at: www.sigar.mil/pdf/quarterlyreports/2015-07-30qr.pdf.

61 'The Prague Summit and NATO's Transformation - A Readers Guide', NATO, 2003, p. 26. 
between the US and European allies about how best to 'manage global security and risk' were difficult to conceal, even as NATO decided to operate 'out-of-area'.

Speaking at the IISS annual conference in September 2007, Jaap de Hoop Scheffer, the NATO Secretary-General, suggested that consensus was in fact emerging within the Alliance about its future direction:

Old terms, such as 'in-' and 'out-of area' no longer apply. All allies acknowledge that, in a globalized world, such definitions have become artificial. They all agree that NATO must be prepared to address security challenges at their source, whenever and wherever they arise. ${ }^{62}$

It was a heroic effort, even if one allows for the platitudinous style demanded by the setting and the occasion. It was not, however, a terribly convincing claim, neither at the time nor when the full force of NATO's fragmented approach and decidedly mixed record in Afghanistan exposed the shallowness of the consensus on NATO's global role. The Prague summit itself had been held against the backdrop of deep rifts among allies about US plans for Iraq. Reaching agreement on a strategic vision did not become any easier in the years that followed. The manifest difficulties of meeting objectives in Afghanistan, with allies increasingly drawn into a full-blown insurgency after 2006, over time added to the sense of that NATO might not, after all, be politically suited and structurally equipped to take on 'security challenges at their source, whenever and wherever they arise'. ${ }^{63}$

This realisation also helps to explain the curious mixture of relief and apprehension, but also rediscovered sense of purpose, permeating NATO's Brussels headquarters by the time the ISAF mission was drawing to a close. Sentiments widely, if not explicitly, articulated in NATO capitals included relief at having disengaged from a costly, divisive, and failing mission in Afghanistan. This was balanced by apprehension and a renewed sense of purpose presented by Russia's forceful assertion of its 'great power' credentials, exemplified by its transparently illegal annexation of Crimea in March 2014 and

62 NATO (2007) 'Managing Global Security and Risk', speech by NATO Secretary General, Jaap de Hoop Scheffer, at IISS Global Strategic Review, 7-9 September.

63 This is discussed more fully in Berdal, Mats and David Ucko (2009) 'NATO at 60', Survival 51(2). 
continuing support for pro-Russian separatist forces in eastern Ukraine. In terms of Alliance cohesion and dynamics, the Russian challenge, while deeply troubling, was also more familiar. Crucially, it engages more directly and unequivocally with what are viewed as the core national interests of the Alliance's members, especially in Eastern Europe.

The second internal driver of institutional response alluded to above was more critical to NATOs actual performance in Afghanistan. This was the range of domestic political pressures and interests held by Alliance members, which framed their contributions to operations in Afghanistan. Unsurprisingly, national interests and perspectives on the mission were not merely - in many cases not even primarily - driven by developments and realities in Afghanistan itself. For European allies, even though they might not share US campaign priorities, supporting US efforts and being seen to do so was always an important consideration in decision-making regarding Afghanistan. This was partly as an act of solidarity but it was also, quite obviously, seen as a matter of profound political interest. According to Sherard Cowper-Coles, who served as UK Ambassador to Kabul and as Special Representative for Afghanistan and Pakistan between 2007 and 2010, 'eagerness to please the Americans' was one of two 'institutional factors' that help explain UK policy towards Afghanistan. ${ }^{64}$ This kind of consideration was not unique to the UK, though each individual ally had to balance it against a different set of domestic priorities and pressures, from electoral cycles and coalition politics, to growing war weariness and financial constraints. The choices made by NATO countries regarding their deployments to Afghanistan - where to deploy, with what resources, and under what caveats - thus reflected a complex mix of domestic political considerations and constraints. ${ }^{65}$ This in turn contributed to the fragmented nature of mission. Those countries deploying to the south in 2006, for example, where fighting

64 Cowper-Coles, Sherard (2015) 'Reflections from Afghanistan', in Rethinking State Fragility, London: The British Academy, p. 22. Available at: www.britac.ac.uk/intl/rethinking-statefragility.cfm.

65 The other institutional factor singled out by Cowper-Coles was the British military, in particular the British Army, which, on the basis of the principle of 'use them or lose them', saw Afghanistan as 'a chance not just to engage the Taliban, but also to engage the Treasury, the Royal Navy, and the Royal Air Force'. Ibid., p. 23. 
was most intense - Denmark, Canada, the Netherlands, UK, and the US - soon formed an inner core of allies, which met separately and from whose decisions other allies were, and felt, excluded.

\section{Concluding Thoughts}

Bob left the IISS for the dreaming spires of Oxford in 1987. Supported and encouraged by him, I travelled the other way in 1992, leaving Oxford and my pre-occupation with NATO and the Cold War of the 1950s for a fellowship at the IISS, where I turned to the United Nations and the disorder of the post-Cold War era.

One consequence of the UN's inability to meet the high expectations of the organisation in the immediate aftermath of the Cold War, was to encourage analysts and governments to call for more effective multilateral mechanisms and institutions to meet new post-Cold war challenges. The search intensified notably following the peacekeeping disasters in Somalia, Rwanda, and former Yugoslavia between 1992 and 1995. Given its capabilities, planning, and tested decision-making structures, NATO, which had already lent its capabilities to the UN in the Balkans, was seen by many as a natural candidate to take on 'crisis management and peacekeeping' tasks. The view that NATO could step in where the cumbersome, ineffective, and under-resourced UN had failed, however, tended to ignore two characteristics common to both organisations, and which crucially continue to influence their functioning. Although profoundly different in many outwardly respects, they are both inter-governmental and deeply political institutions. As such, the range of interests held by their member states - reflecting different historical perspectives, values, and understandings of threats and challenges to international peace and security - will always complicate the search for coherence and unity of effort. The history of NATO's mission in Afghanistan has shown that in this respect, at least, there are parallels to draw between otherwise markedly different organisations. 
This text is taken from War, Strategy and History: Essays in Honour of Professor Robert O'Neill, edited by Daniel Marston and Tamara Leahy, published 2016 by ANU Press, The Australian National University,

Canberra, Australia. 